\title{
UNPALATABLE DECISIONS BY INTERNATIONAL COURT OF JUSTICE (ICJ) AND PALATABLE SOLUTIONS BY ISLAMIC INTERNATIONAL LAW (SIYAR)
}

\author{
Muhammad Naguib Bin Abdul Malik, PhD Candidate, \\ Faculty of Law, University of Malaya, Malaysia. \\ E-mail:muhammadnaguib8888@gmail.com
}

\begin{abstract}
This article demonstrates that the cases decided by the ICJ and the arbitration tribunals are judge made law and are not derived from the rules of customary law. Judge made law, as enunciated by the ICJ and the arbitration tribunals are very general and imprecise. The decisions made by the ICJ and the arbitration tribunals beget unpredictability or unexpected results. Normally, state parties are not happy with the decision made by the ICJ and the arbitration tribunals and the discontented states are unable to take any actions as state parties need to comply with the decision of the ICJ. In this Article, two (2) cases, one in South America and the other one in Africa, were discussed in detail. The outcome of these two (2) cases is not palatable to some state parties. Since the decisions are not predictable and the outcome is not palatable to some state parties, this Article looks at possible solutions which are being offered in International Islamic Law (Siyar).
\end{abstract}

Keywords: Islamic International Law (Siyar), International Court of Justice (ICJ), Judge Made Law, Maritime Boundary Delimitations, Unpredictable Results, The Principle of Joint Administration, The Principle of Joint Development.

\section{INTRODUCTION}

The decisions made by the ICJ and the arbitration tribunals have significant influence on how boundary settlements or agreements have been concluded. The ICJ and the arbitration tribunals have substantial influence over maritime boundary delimitation law.

The main source of maritime boundary delimitation law is customary international law coupled with state practice and also any existing boundary agreements. Any awards or judgments granted by 
the tribunals or the ICJ would determine the states' obligations in this arena of international law and at the same time, the awards or judgments granted by the tribunals or the ICJ would also determine the international political and economic scenarios.

\section{The Maritime Boundary Delimitations Law Derived From Judge Made Law}

Prosper Weil was of the opinion that the customary international law of maritime delimitations is not being applied or used in state practise mainly because most of the maritime boundary delimitations law is derived from judge made law i.e. derived from the law making power of the ICJ.

The prevailing issues relating to economic, resource, security, defence and navigational factors are currently not taken into consideration by the ICJ and tribunals. Kwiatkowska is of the opinion that the aforesaid factors should be taken into consideration by the ICJ and tribunals in territorial sea, straits, Exclusive Economic Zone (EEZ) and Continental Shelf (CS) delimitations. At the same time, coastal states are also entitled to exercise their rights upon the water column and surface areas of delimited areas.

Charney argues that fisheries, mineral resources and environmental consideration are relevant to the delimitation of maritime spaces or zones under the national jurisdiction of states. States have diverged the expressed delimitation treaties from the delimitation cases which were decided by the ICJ.

The Rules of Customary Law Enunciated are Very General and Imprecise. The parties have to refer their dispute to a third party i.e. the ICJ and the tribunals in order to achieve an equitable solution. ${ }^{1}$ According to R.R Churchill and A.V Lowe ("the Authors") ${ }^{2}$, this means that neither state may take any action in the disputed area that may be viewed as prejudicial by the other party. For example, the exploratory drilling for oil and gas on a disputed area

Article 83(2) of UNCLOS

Churchill, R. R. and A. V Lowe, (1999), The Law of the Sea, 3rd edition, Manchester University: Juris Publishing, at 193 
is regarded as prejudicial by the other state. ${ }^{3}$ The Authors argued that such an obligation also exists under customary international law. ${ }^{4}$ The customary international law prohibits unilateral exploitation in disputed areas, pending maritime boundary delimitation or other alternative arrangements provided by the ICJ or devised by the states in solving their dispute. ${ }^{5}$

The Authors argued that the customary international law in relation to the delimitation of CS boundaries has been developed through the awards made by arbitral tribunals ${ }^{6}$ and decisions by the ICJ ${ }^{7}$. The Authors viewed that the ICJ and tribunals did not ascertain or find out what the rules of customary international law were, but instead, the ICJ and tribunals simply made a declaration as to what customary international law was. Thus, the customary international law rules that we are dealing with are actually judge made law. ${ }^{8}$

The Authors stated that the ICJ and tribunals were having tough time to determine what customary law was, 'the International Court and tribunals have faced with the almost impossible task of trying to formulate a rule of sufficient generality to be applicable to a wide variety of geographical circumstances', ${ }^{9}$ despite of having such difficulty, the ICJ and tribunals were able to determine and predict the boundaries in the particular case of Gulf of Maine..$^{10}$ Possibly, this is what prompted the ICJ in the Gulf of Maine case ${ }^{11}$ to conclude that a distinction was to be made between principles of delimitation and practical methods of determining boundaries. Accordingly, only the former could be the subject of customary international law. According to the Authors, the ICJ and tribunals have been, so far, not very successful in determining what customary international law is. Thus, 'the rules of customary law they have enunciated are, as will be seen, very general and imprecise.' ${ }^{12}$

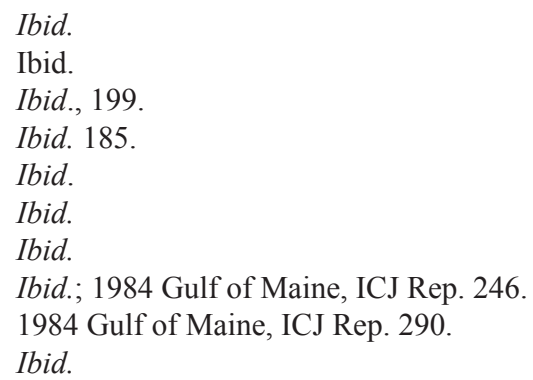


In the North Sea Continental Shelf cases $^{13}$, after observing that there is no single method of delimitation, the court stated that under customary international law, delimitation is to be effected according to equitable principles, by taking account of all the relevant circumstances ${ }^{14}$. The outcome of the decision made by the ICJ gave 'Germany a larger share of the shelf than it would have enjoyed under a delimitation employing only the equidistance principle'. ${ }^{15}$ This decision created an uproar or dissatisfactory reactions by legal scholars.

Since the decision in the Tunisia/Libya case, ${ }^{16}$ the ICJ has emphasised that the goal of the delimitation process is the achievement of an equitable result. ${ }^{17}$ It is interesting to note that the ICJ in the case of North Sea Continental Shelf ${ }^{18}$ contends that the delimitation rule in Article 6 of the 1958 Geneva Convention is not regarded as customary rules. ${ }^{19} \mathrm{We}$ could see that how the tribunals and ICJ have been reluctant to enumerate the principles of delimitation under customary law. ${ }^{20}$

In the case of opposite coasts, the delimitation process before the ICJ has been initiated by drawing a line of equidistance as a provisional boundary. ${ }^{21}$ The ICJ would then decide whether the provisional boundary needs to be modified in accordance with the relevant circumstances for the purpose of arriving at an equitable solution..$^{22}$

In relation to the issues of 'relevant circumstances' and 'special circumstances'. 'Article 6 of the 1958 Geneva Convention requires consideration of any 'special circumstances' which might justify a departure from the median line when drawing a CS

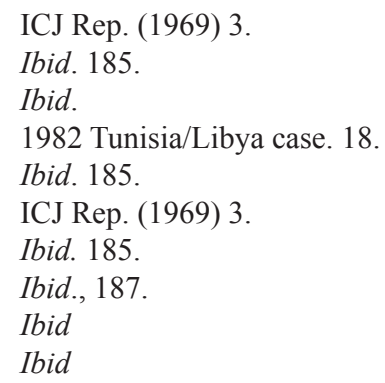


boundary", "whereas customary international law requires 'relevant circumstances' to be taken into account. ${ }^{23}$

In the North Sea Continental Shelf ${ }^{24}$ cases, the ICJ indicated that there is no limit to the kind of circumstances or factors that could be taken into account when effecting an equitable delimitation. ${ }^{25}$

If we refer to the cases passed down by the ICJ, we find that there is a degree of consistency in the case law where the ICJ maintains a wide discretion in applying or adopting relevant circumstances which it selects and what relative importance is awarded to each of them in a given case. Therefore, under customary international law, states are free to agree on any boundary for their overlapping EEZ. If they are unable to agree, the matter is to be referred to third party dispute settlement. Thus, the ICJ and tribunals would draw the boundary line by applying equitable criteria while considering all the relevant circumstances of the case so as to achieve an equitable result.

\section{THE ASSESSMENT UPON THE EXISTING LAW OF MARITIME BOUNDARY DELIMITATION}

\section{The Developments of the Law of Maritime Boundary Delimitation}

The developments and origins of the law of maritime boundary delimitation have come a long away. This started in Article 38 of the statute of the ICJ which provides a list of international law sources, namely international conventions, international custom, general principles of law recognised by civilised nations, judicial decisions and the teachings of the most highly qualified publicists.

Article 38 (1), which describes the law to be applied by the ICJ when deciding cases within its jurisdiction, is generally considered to be the most authoritative enumeration of the sources of International Law.

\footnotetext{
Ibid. 187.

ICJ Rep. (1969) 3.

25 Ibid at 50.
} 
The term 'equitable solution' as stated in Articles 74 and 75 of 1982 LOSC is vague in nature where the aforesaid articles do not stipulate in detail as to what is 'equitable solution'. The reason the aforesaid articles were designed in such manner could be traced back during the early drafting of UNCLOS. ${ }^{26}$ The participants during UNCLOS III discovered that they were divided into two different camps, namely:-

i. First camp

This first camp is dedicated to the support of 'equidistance/ special circumstances' rule where in the absence of agreement on a boundary ${ }^{27}$ 'and unless another boundary line is justified by special circumstances, the boundary shall be determined by application of the principle of equidistance from the nearest points of the baselines from which the breadth of the territorial sea of each State is measured.'

ii. Second camp

This second camp rejected the notion of equidistance and resorted to equitable principles ${ }^{28}$.

Thus, the term 'equitable solution' was drafted in a manner to please the two camps and as a result, the term 'equitable solution' brings more vagueness rather than clarity. ${ }^{29}$ Articles 74 and 83 of the 1982 LOSC do not actually refer to either equidistance or equitable principles ${ }^{30}$ but they refer to delimitation by agreement. ${ }^{31}$

In the principle of 'equidistance or the special circumstances' rule, one should take note that in the absence of agreement between states, the equidistance principle could not be applied to the parties without looking at the special circumstances. ${ }^{32}$

\footnotetext{
26 Sun Pyo Kim, (2004), Maritime Delimitation and Interim Arrangements in North East Asia, Dordrecht: Martinus Nijhoff Publishers, 32-33

27 Id. at 191.

28 Ibid. at 191.

29 Ibid.

30 Ibid.

31 Ibid.

32 I.C.J. Reports 2001, p.111, para.231
} 
As for the principle of equity, the law exists to embody the notion of justice. The concept of justice and the concept of law that revolve around the principles of equity and equidistance are worlds apart and do not complement each other. ${ }^{33}$ Since these two principles could not complement each other, the notions of justice, certainty, clarity and predictability could not be presented to the parties. ${ }^{34}$

This is the reason why the notion of predictability does not exist in matters arising from maritime delimitation law. ${ }^{35}$ Thus, parties who referred their cases to the ICJ would normally get unexpected results.

Since the notion of predictability is a 'hard commodity' in maritime delimitation law, parties have resorted to negotiation and if negotiation fails, they opt for adjudication. ${ }^{36}$

\section{PARTIES WHICH REFERRED THEIR DISPUTES TO THE ICJ RECEIVED UNEXPECTED RESULTS}

There are cases where the ICJ gave unexpected results. This article would be discussing the following two (2) cases which have unexpected results, namely:-

i) Cameroon v. Nigeria Case (2002); and

ii) Colombia v. Nicaragua (2012);

\section{Analysis on the Discontent}

In the above cases, the states parties had to accept the decisions made by the ICJ because under normal circumstances, states parties which would refer their cases to the ICJ would agree that the decisions of their cases would not be appealed against. However, the decisions made by the ICJ have led to discontent among the states parties.

\footnotetext{
33 Ibid.

34 Antunes, N. S. M. 'The Pending Maritime Delimitation in the Cameroon v. Nigeria Case: A Piece in the Jigsaw Puzzle of the Gulf of Guinea', International Journal of Marine and Coastal Law, 15, 2000, at 179.

35 Ibid.

36 Ibid. at 183
} 


\section{Discontent of State Parties in Africa}

\section{Cameroon v. Nigeria Case (2002)}

Cameroon filed a case before the ICJ in March 1994 and the ICJ delivered its judgment on 10 October $2002 .{ }^{37}$ In this case, Cameroon raised a dispute relating 'essentially to the question of sovereignty over the Bakassi Peninsula'. ${ }^{38}$ At the same time, Cameroon raised the issue of sovereignty over Cameroonian territory in the area of Lake Chad and the frontier between Cameroon and Nigeria from Lake Chad to the sea. ${ }^{39}$

Cameroon raised the question of sovereignty over the Bakassi Peninsula. Cameroon relied upon the following treaties ${ }^{40}$ :-

a) Anglo-German Agreements of 1913;

b) Yaoundé II Declaration, 1971; and

c) Maroua Declaration, 1975

The first of Anglo-German Agreements of 1913, signed in London on 11 March 1913 (hereinafter, the "Anglo-German Agreement of 11 March 1913"), concerned "(1) The Settlement of the Frontier between Nigeria and the Cameroons, from Yola to the Sea and (2) The Regulation of Navigation or the Cross River" and covered some $1,100 \mathrm{~km}$ of boundary; the second, signed at Obokum on 12 April 1913 by Hans Detzner and W. V. Nugent representing Germany and Great Britain respectively (hereinafter the "Anglo-German Agreement of 12 April 1913"), concerned the Demarcation of the Anglo-German Boundary between Nigeria and the Cameroons from Yola to the Cross River and included eight accompanying maps. ${ }^{41}$

Land and Maritime Boundary between Cameroon and Nigeria, The Hague Justice Portal, http://www.haguejusticeportal.net/index.php?id=6220 Date Accessed 23 February 2013

38 Ibid.

39 Ibid.

40 International Court of Justice, Reports of Judgments, Advisory Opinions and Orders, Case Concerning the Land and Maritime Boundary Between Cameroon and Nigeria (Cameroon v. Nigeria: Equatorial Guinea intervening), Judgment of 10 October 2002, at page 6

$41 \mathrm{Ibid}$. at page 32 
Cameroon contended that "the Anglo-German Agreement of 11 March 1913 fixed the course of the boundary between the Parties in the area of the Bakassi Peninsula, placing the latter on the German side of the boundary. Hence, when Cameroon and Nigeria acceded to independence, this boundary became the separation line between the two countries, successor States to the colonial powers and bound by the principle of uti possidetis." 42

On the other hand, Nigeria argued that "title lay in 1913 with the Kings and Chiefs of Old Calabar, and was retained by them until the territory passed to Nigeria upon independence. Great Britain was therefore unable to pass title to Bakassi because it had no title to pass (nemo dut quod non habet): as a result, the relevant provisions of the Anglo-German Agreement of 11 March 1913 must be regarded as ineffective." ${ }^{43}$

The court was of the opinion that "the Treaty with the Kings and Chiefs of Old Calabar did not specify the territory to which the British Crown was to extend "gracious favour and protection", and it did not indicate the territories over which each of the Kings and Chiefs signatory to the Treaty exercised his powers. However, the consul who negotiated and signed the Treaty, said of Old Calabar "this country with its dependencies extends from Tom Shots . . . to the River Rumby (on the west of the Cameroon Mountains), both inclusive". Some six years later, in 1890, another British consul, Johnston, reported to the Foreign Office that "the rule of the Old Calabar Chiefs extends far beyond the Akpayafe River to the very base of the Cameroon Mountains". The Court observes that, while this territory extends considerably eastwards of Bakassi, Johnston did report that the Old Calabar Chiefs had withdrawn from the lands east of the Ndian. Bakassi and the Rio del Rey lay to the west of the Ndian, an area referred to by Johnston as "their real, undoubted territory"." 44 Thus, "the Court has been presented with no evidence of any protest in 1913 by the Kings and Chiefs of Old Calabar; nor

\footnotetext{
$42 \quad$ Ibid. at page 101

43 Ibid.

44 Ibid. at page 105
} 
of any action by them to pass territory to Nigeria as it emerged to independence in $1960 " .45$

At the same time, Nigeria contended that, "under contemporary German domestic legislation, all treaties providing for cession or acquisition of colonial territory by Germany had to be approved by Parliament". It points out that the Anglo-German Agreement of 11 March 1913 was not so approved. It argues that the Agreement involved the acquisition of colonial territory, namely the Bakassi Peninsula, and accordingly ought to have been "approved by the German Parliament, at least so far as its Bakassi provisions were concerned"."

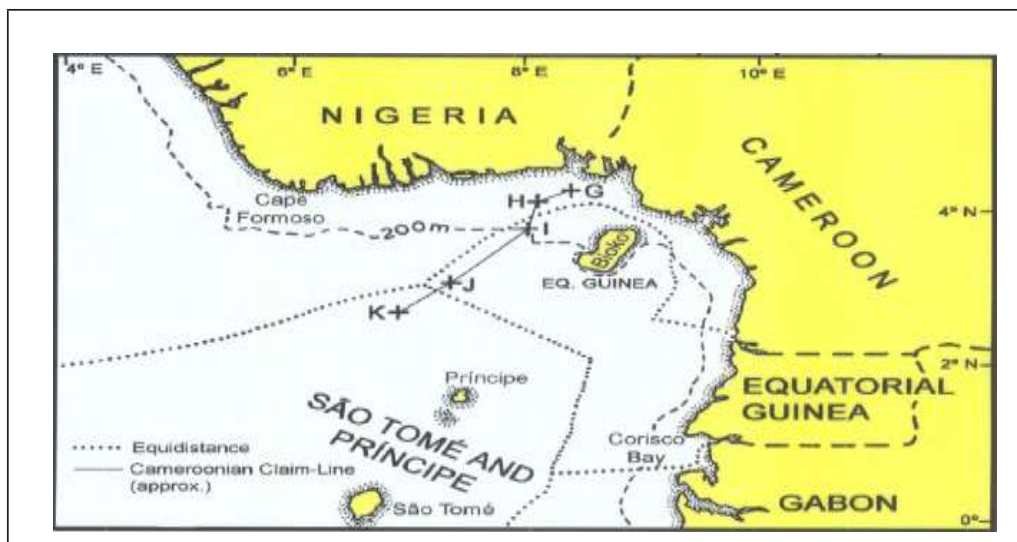

Figure 1. Cameroon v. Nigeria 2002

The Court was of the opinion that the Anglo-German Agreement of 11 March 1913 "had, moreover, been officially published in both countries. It is therefore irrelevant that the Anglo-German Agreement of 11 March 1913 was not approved by the German Parliament. Nigeria's argument on this point accordingly cannot be upheld." ${ }^{47}$

\footnotetext{
45 International Court of Justice, Reports of Judgments, Advisory Opinions and Orders, Case Concerning the Land and Maritime Boundary Between Cameroon and Nigeria (Cameroon v. Nigeria: Equatorial Guinea intervening), Judgment of 10 October 2002, at pages 107 and 108

46 Ibid. at page 101

47 Ibid. at page 102
} 
In regards to Yaounde II Declaration, the court finds that it is clear that Bakassi belongs to Cameroon ${ }^{48}$ on the basis that "in 1970 Cameroon and Nigeria decided to carry out a total delimitation and demarcation of their boundaries, starting from the sea. Under the terms of Article 2 of the Yaoundé I Declaration of 14 August 1970 and the agreement reached in the Yaoundé II Declaration of 4 April 1971 with its signed appended chart, it was agreed to fix the boundary in the Akwayafe estuary from point 1 to point 12 ...". Then, by declaration signed at Maroua on 1 June 1975, the two Heads of State "agreed to extend the delineation of the maritime boundary between the countries from Point 12 to Point G on the Admiralty Chart No. 3433 annexed to this Declaration" and precisely defined the boundary by reference to maritime Co-ordinates." ${ }^{49}$ Nigeria also argued that Maroua Declaration was not valid in international law because it was not rectified. ${ }^{50}$

In relation to Maroua Declaration, the court was of the opinion that "Nigeria clearly and publicly recognised Cameroon title to Bakassi. That continued to be the position until at least 1975, when Nigeria signed the Maroua Declaration. No Nigerian effectivités ${ }^{51}$ in Bakassi before that time can be said to have legal significance for demonstrating a Nigerian title; this may in part explain the absence of Cameroon protests regarding health, education and tax activity in Nigeria. 'The Court also notes that Cameroon had since its independence engaged in activities which made clear that it in no way was abandoning its title to Bakassi. Cameroon and Nigeria participated from 1971 to 1975 in the negotiations leading to the Yaoundé, Kano and Maroua Declarations, with the maritime line clearly being predicated upon Cameroon's title to Bakassi. Cameroon also granted hydrocarbon licences over the peninsula and its waters, again evidencing that it had not abandoned title in the face of the

\footnotetext{
Ibid. at page 112

Ibid.

Ibid. at page 6

Anthony Aust defines effectivités as "Sovereign activities (effectivités) in relation to the territory by the disputing States" quoted from Anthony Aust, Handbook of International Law, Second Edition, Cambridge University Press, 2010 , at page 38
} 
significant Nigerian presence in Bakassi or any Nigerian effectives contra legem. And protest was immediately made regarding Nigerian military action in 1994." 52

There are several issues that are worth discussing, namely:-

i) The ICJ referred to Treaties and Agreements regarding Maritime Boundar

The court in this case referred to numerous treaties in order to determine the question of maritime boundary whether it was settled by the parties prior to this case being referred to the court. Nigeria disputed the validity of the treaties and agreements referred by the court. The court referred to the treaties and agreements for the purpose of interpreting the treaties in question and the ICJ reached a decision based on the interpretation of the treaties and agreements. ${ }^{53}$

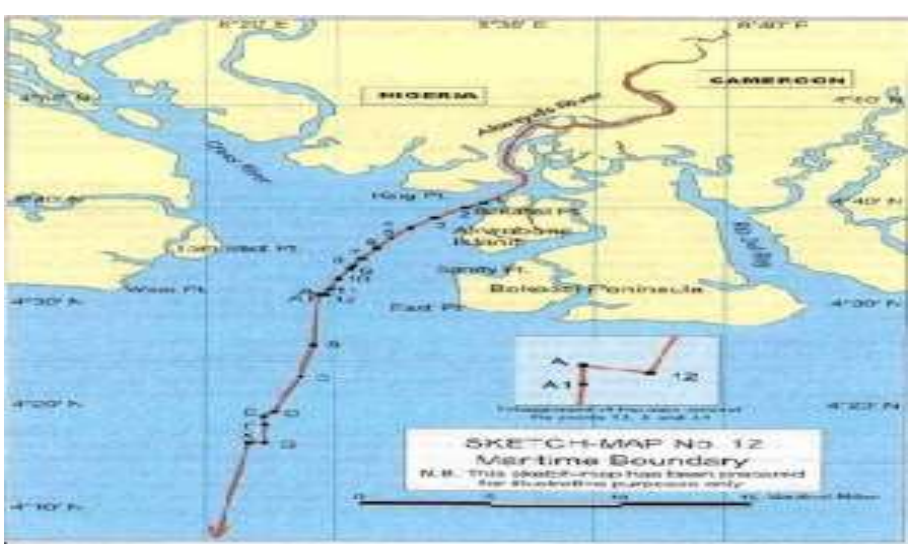

Figure 2. Nigeria, Cameroon - and Bakassi Peninsula ${ }^{54}$

$52 \quad$ Ibid. at page 117

53 Shi Jiuyong, Maritime Delimitation in the Jurisdiction of the International Court, Oxford Journals, Law \& Social Sciences, Chinese Journal of International Law, Volume 9, Issue 2, Pg. 271-291, at page 278.

54 International Court of Justice, Reports of Judgments, Advisory Opinions and Orders, Case Concerning the Land and Maritime Boundary Between Cameroon and Nigeria (Cameroon v. Nigeria: Equatorial Guinea intervening), Judgment of 10 October 2002, at page 441 at para. 228, at page 150 
ii) The Equitable Principle or Relevant Circumstances Method The court in this case, was discussing the equitable principle or relevant circumstances method, and stipulated that ${ }^{55}$ :

"This method, which is very similar to the equidistance/ special circumstances method applicable in delimitation of the territorial sea, involves first drawing an equidistance line, then considering whether there are factors calling for the adjustment or shifting of that line in order to achieve an 'equitable result'." ${ }^{56}$

The delimitation of the CS and the EEZ of both adjacent and opposite coasts, the court in this case drew an equidistance line and then the court consider whether there are other circumstances which must lead to an adjustment of that line. In this case, the final delimitations were modified equidistance lines. ${ }^{57}$

The court decided that sovereignty over the Bakassi Peninsula lies with Cameroon and that the boundary is delimited by the AngloGerman agreement of 11 March $1913 .^{58}$ The court noted that the land boundary dispute 'falls within an historical framework' including partition by European powers in the 19th and early 20th centuries, League of Nations mandates, UN Trusteeships and the independence of the two states. ${ }^{59}$

The court also ruled on the $1690 \mathrm{~km}$ border between Lake Chad and the sea, the maritime boundary, and issues of state responsibility. ${ }^{60}$ The court requested that both Nigeria and Cameroon withdraw their administration and their military and police forces from certain areas

\footnotetext{
Ibid.

56 International Court of Justice, Reports of Judgments, Advisory Opinions and Orders, Case Concerning the Land and Maritime Boundary Between Cameroon and Nigeria (Cameroon v. Nigeria: Equatorial Guinea intervening), Judgment of 10 October 2002, at page 441 at para. 228

57 Id. at page 284

58 Land and Maritime Boundary between Cameroon and Nigeria, The Hague Justice Portal, http://www.haguejusticeportal.net/index.php?id=6220 Date Accessed 23 February 2013
}

59 Ibid.

60 Ibid. 
according to the judgment. ${ }^{61}$ Nigeria agreed to withdraw its troops from the Bakassi region in accordance with the 2002 judgment under a deal brokered by the United Nations. ${ }^{62}$

The following are the criticism or unexpected results of this case:-

i) Non-Inclusion of the relevant Coast of Cameroon which faced Equatorial Guinea's Bioko Island

The court in this case did not include in the relevant coast which is part of the coast of Cameroon which faced Equatorial Guinea's Bioko Island. ${ }^{63}$ This is relevant to delimit between Cameroon and Equatorial Guinea rather than Cameroon and Nigeria. ${ }^{64}$

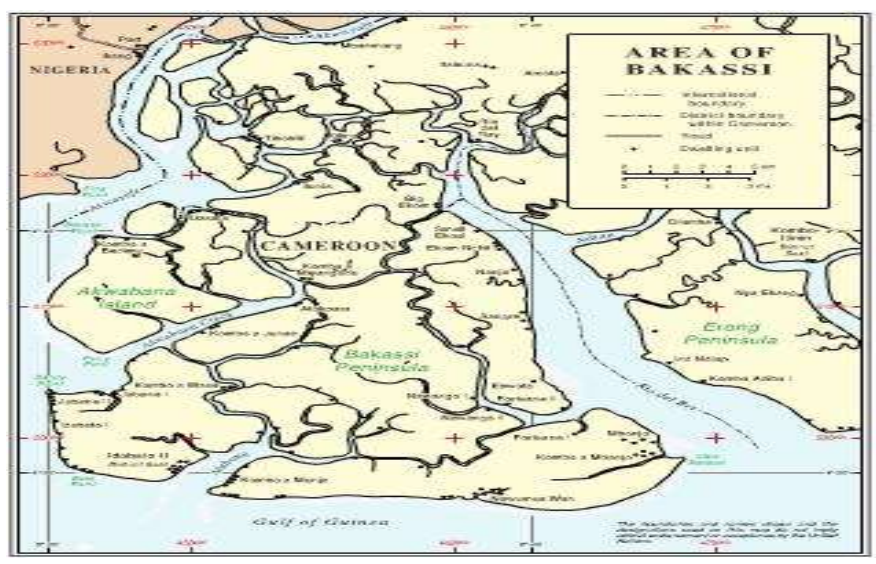

Figure 3. Area of Bakassi ${ }^{65}$

\footnotetext{
Ibid.

Ibid.

63 International Court of Justice, Reports of Judgments, Advisory Opinions and Orders, Case Concerning the Land and Maritime Boundary Between Cameroon and Nigeria (Cameroon v. Nigeria: Equatorial Guinea intervening), Judgment of 10 October 2002, at pages 442-443 at para. 291; SHI Jiuyong (fn 61) at page 276. Ibid.

65 Map obtained from Energy-Pedia News, Cameroon to open coastal areas for oil exploration, 6 April 2010 http://www.energy-pedia.com/news/cameroon/ cameroon-to-open-coastal-areas-for-oil-exploration Date Accessed 24 February 2013
} 
ii) Issue of Relevant Circumstances

In this case, the court has rejected the claim of using oil concessions and oil wells as relevant circumstances in maritime boundary adjustment. This stated as follows:-

"oil concessions and oil wells are not in themselves to be considered as relevant circumstances justifying the adjustment or shifting of the provisional delimitation line." ${ }^{66}$

iii) The ICJ referred to the Anglo-German agreement of 11 March 1913

Basically, the unexpected result of this case is caused by the court having referred to the Anglo-German agreement of 11 March 1913 where the boundary is delimited and based on this agreement the Court decided that sovereignty over the Bakassi Peninsula lies with Cameroon. ${ }^{67}$

The Court decided that sovereignty over the Bakassi Peninsula lies with Cameroon and that the boundary is delimited by the AngloGerman agreement of 11 March 1913.Thus, the ICJ would refer to treaties and agreements in order to settle disputes even though Nigeria has been controlling Bakassi Peninsula even since her independence from the British. The Anglo-German agreement of 11 March 1913 is the turning point where Cameroon was able to gain sovereignty over the Bakassi Peninsula.

Nigeria was not happy with the ICJ decision as evident by the official statement by Nigeria whereby it rejected parts of the judgment as unacceptable. Cameroon, on the other hand, has obtained vast territories that are rich in mineral and oil resources. Thus, the decision made by the ICJ has led to discontent on the part of Nigeria.

66 International Court of Justice, Reports of Judgments, Advisory Opinions and Orders, Case Concerning the Land and Maritime Boundary Between Cameroon and Nigeria (Cameroon v. Nigeria: Equatorial Guinea intervening), Judgment of 10 October 2002, at pages 447-448 at para. 304;SHI Jiuyong (fn 61) at page 289

67 Land and Maritime Boundary between Cameroon and Nigeria, The Hague Justice Portal, http://www.haguejusticeportal.net/index.php?id=6220 Date Accessed 23 February 2013 


\section{Discontent of State Parties in South America}

\section{Colombia v. Nicaragua (2012)}

Nicaragua filed an application with the ICJ on 6 December 2001 and the ICJ issued its decision on 19 November 2012. In this case, Nicaragua wanted to institute proceedings against Colombia in respect of a dispute "concerning title to territory and maritime delimitation" in the western Caribbean. ${ }^{68}$

This case started with the 1928 Barcenas-Esguerra Treaty which dealt with issues of sovereignty of islands in the western Caribbean. Since then, there were no disputes between the two countries because the 1928 treaty had dealt with $3 \mathrm{~nm}$ of territorial seas.$^{69}$ Based on this 1928 treaty, Colombia exercised sovereignty over several habitable islands, namely San Andres, Providencia and Santa Catalina which were $380 \mathrm{~nm}$ from the Colombian coast and $50 \mathrm{~nm}$ to $125 \mathrm{~nm}$ from the Nicaraguan coast. The isles of Quitasueňo and Serrana were not covered by the 1928 treaty but Colombia has always regarded the isles as belonging to them. ${ }^{70}$

The notion of resources of the CS become more relevant in the second half of the $20^{\text {th }}$ century, Nicaragua believes that the terms of the 1928 Treaty are disadvantageous. ${ }^{71}$ Nicaragua regarded her position as inequitable when the new era of extended jurisdiction and maritime resource exploitation began. ${ }^{72}$ Nicaragua took the case feeling confident that the court would award it with sovereignty over the key islands ${ }^{73}$ as they were closer in distance to Nicaragua.

68 Territorial Dispute and Maritime Delimitation (Nicaragua v. Colombia), International Court of Justice, Summary of the Judgment of 19 November 2012, at page 1 .

69 Professor Steven Haines, A Note On The ICJ Judgment In Nicaragua V Colombia and its relevance to International Crime and Criminal Law, January 2, 2013, at page 2 http://acontrarioicl.com/2013/01/02/a-note-on-the-internationalcourt-of-justice-judgement-in-nicaragua-v-colombia-and-its-relevance-tointernational-crime-and-criminal-law/ Date Accessed:- 21 February 2013

70 Ibid.

71 Ibid.

72 Ibid.

73 Ibid. 
Issues

i. Rock or island?

The court decided Quitasueño is not an island as claimed by Colombia. Thus, Quitasueño could be defined as a rock as per Article 121 (3) of the 1982 LOSC. ${ }^{74}$ The court was of the view that Quitasueño should not to be considered to have the median line. The base point should be located on Santa Catalina, Providencia and San Andrés islands and on Alburquerque Cays. ${ }^{75}$

The court held that Quitasueño and Serrana were allowed to have a territorial sea which was $12 \mathrm{~nm}$ in breadth. At the same time, the court stressed that Quitasueño is not allowed to have CS or EEZ because Quitasueño was incapable of sustaining human habitation or an economic life of its own. ${ }^{76}$ The court did not grant Providencia $200 \mathrm{~nm}$ in breadth because it would overlap the CS and EEZ generated by the islands of San Andrés and Santa Catalina. ${ }^{77}$

As for Serrana, the court stipulated that whether Serrana is a rock or otherwise, Serrana should be given $12 \mathrm{~nm}$ due to "its small size, remoteness and other characteristics [which] mean that, in any event, the achievement of an equitable result requires that the boundary line follow the outer limit of the territorial sea around the island." ${ }^{.78}$

ii. Commission on the Limits of the Continental Shelf (CLCS) Nicaragua raised the question of the CLCS. In Article 76(1) of the 1982 LOSC, it states the general principle:

\footnotetext{
74 Territorial Dispute and Maritime Delimitation (Nicaragua v. Colombia), International Court of Justice, Summary of the Judgment of 19 November 2012 , at page 2 .

Ibid. at page 7 .

Ibid. at page 10

Ibid. at page 7

Ibid at page 11
} 
"The continental shelf of a coastal State comprises the seabed and subsoil of the submarine areas that extend beyond its territorial sea throughout the natural prolongation of its land territory to the outer edge of the continental margin, or to [an automatic] distance of 200 nautical miles from [its] baselines."

The Court said that the $200 \mathrm{~nm}$ or "the outer edge of the continental margin" could be found in the customary international law. "The outer edge of the continental margin" is the CS beyond $200 \mathrm{~nm}$ where the party must make a submission to the CLCS. Under Article $76(8)$, there is an obligation upon the parties to submit the limits of their CS beyond $200 \mathrm{~nm}$ to the CLCS.

On the other hand, Nicaragua is a party to the 1982 LOSC and Colombia is not. The court solves that issue by stating that since Colombia is not a party, this would not relieve Nicaragua under Article 76 of the 1982 LOSC. ${ }^{80}$ The reason Nicaragua raised the issue of CLCS was that Nicaragua wanted to argue that in certain areas of its geological CS, it has reached Columbia's $200 \mathrm{~nm}$. Thus, Nicaragua could argue that a median line should be drawn thus giving partial effect on the geological shelf.

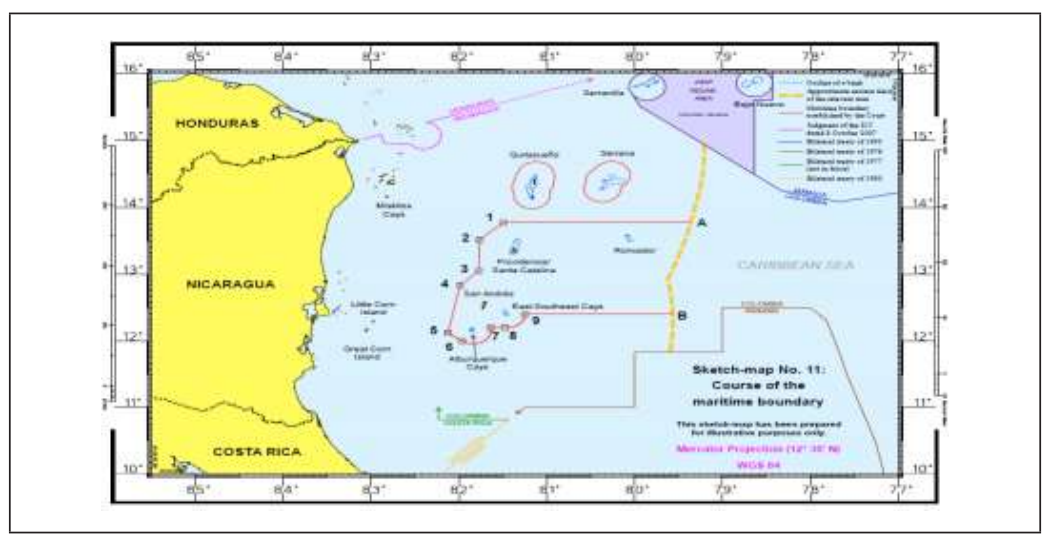

79 Territorial Dispute and Maritime Delimitation (Nicaragua v. Colombia), International Court of Justice, Summary of the Judgment of 19 November 2012, at para 118

80 Territorial Dispute and Maritime Delimitation (Nicaragua v. Colombia), International Court of Justice, Summary of the Judgment of 19 November 2012, at para 126 
The court rejected Nicaragua's request to delimit the outer edge of the CS margin. The court stated that:-

"However, since Nicaragua, in the present proceedings, has not established that it has a continental margin that extends far enough to overlap with Colombia's 200-nautical-mile entitlement to the continental shelf, measured from Colombia's mainland coast, the Court is not in a position to delimit the continental shelf boundary between Nicaragua and Colombia, as requested by Nicaragua, even using the general formulation proposed by it."

Nicaragua referred this matter to the ICJ because Nicaragua wanted to achieve two (2) objectives, namely:-

i) "A ruling that it has sovereignty of various islands and cays located between Nicaragua and Colombia" $"$; and,

ii) "the delimitation by the Court of the maritime boundary between the two States." ${ }^{22}$

The case was complex at the technical level. The court concluded that Columbia has the sovereignty over the islands of San Andrea, Providencia and Santa Catalina because the 1928 Treaty clearly stipulates that the aforesaid islands belong to Colombia. ${ }^{83}$ At the same time, Columbia has sovereignty over Quitasueño and Serrana. ${ }^{84}$

In relation to the issue of the delimitation by the court of the maritime boundary between the two states, Columbia lost the extensive sea area (approximately 30,000 square miles of ocean) as a result of the ruling. ${ }^{85}$

The ICJ's judgment is legally binding on the parties. It is unlikely for both Colombia and Nicaragua to go to war over the decision ${ }^{86}$ but the likelihood of Columbia waging war in the future is unknown.

\footnotetext{
81 Professor Steven Haines (fn 77) at page 4

82 Ibid

${ }^{83}$ Ibid. at page 5

84 Ibid.

85 Professor Steven Haines (fn 77) at page 5; Territorial Dispute and Maritime Delimitation (Nicaragua v. Colombia), International Court of Justice, Summary of the Judgment of 19 November 2012,at pages 11 and 12.

86 Professor Steven Haines (fn 77) at pages 5 and 6.
} 
This case might create potential claims for coastal states to assume rights and impose obligations on other states to observe the 1982 LOSC even though the other states are not part of the 1982 LOSC. ${ }^{87}$ Thus, the court, in applying the principles of UNCLOS through customary law, is subtly "enforcing" the 1982 LOSC upon Columbia.

Colombia was clearly not happy with the ICJ decision as demonstrated in the statement by the Colombian president, Juan Manuel Santos, that the ICJ has made error in judgment by giving Nicaragua a large chunk of territory around the island of San Andrea. ${ }^{88}$ However, Colombia has not taken any action against the ICJ ruling perhaps due to the limited actions. ${ }^{89}$ Thus, the decisions made by the ICJ have led to discontent on the part of Colombia.

\section{SUMMARY OF THE EQUITABLE PRINCIPLES AS DECIDED IN THE CASE LAW OF THE ICJ AND THE TRIBUNALS}

The outcomes of the aforesaid cases are stated herewith:-

\section{The Unpredictability or Unexpected Results}

The unpredictability or unexpected results of the aforesaid cases as mentioned above would bring unexpected results in relation to the issues of boundaries to many nations if such issues were to be referred to the ICJ and the tribunals as almost every country in the world is involved in a territorial dispute, namely ${ }^{90}:-$

i. Australia (claims on Antarctica and maritime disputes with Indonesia);

ii. Canada and the United States (dispute on how to divide the Beaufort Sea and the status of the Northwest Passage but continue to work cooperatively to survey the Arctic continental shelf);

Ibid. at page 9

Ibid.

Ibid.

90 Eileen Shim, Almost Every Country in the World Is Involved in a Territorial Dispute — Including the U.S, 2014, http://www.policymic.com/articles/86161/ almost-every-country-in-the-world-is-involved-in-a-territorial-disputeincluding-the-u-s Date Accessed 8 June 2014 
iii. The Bahamas and U.S. (both have not been able to agree on a maritime boundary);

iv. Brazil (boundary dispute with Uruguay);

v. Denmark (dispute with Canada over Hans Island); and

vi. France (multiple disputes over Bassas da India, Europa Island, Glorioso Islands, Juan de Nova Island, Mayotte, Tromelin Island, French Guiana, Antarctica, Matthew and Hunter Islands).

The list above is non-exhaustive in nature. However, in South East Asia, there are two cases which were referred to the ICJ which resulted in decisions which are not palatable to state parties, namely the Sipadan and Ligitan Case in 2002 and the Case Concerning Sovereignty over Pedra Branca/Pulau Batu Puteh, Middle Rocks and South Ledge (Malaysia/Singapore) 2008. The brief outline of these cases are explained below herewith:-

i) The effects of the ICJ decision of Sipadan and Ligitan Case in 2002

The dispute Sipadan and Ligitan Islands started in 1969 when Malaysia and Indonesia negotiated to delimit their continental shelf off Sulawesi Sea. ${ }^{91}$ Malaysia and Indonesia could not agree on the sovereignty of Sipadan and Ligitan islands, the continental shelf border was not delimited. ${ }^{92}$ Both state parties referred their disputes to the ICJ. The ICJ found that neither parties has a treaty-based title to Ligitan and Sipadan, the ICJ next considered the question of whether Indonesia or Malaysia could hold title to the disputed islands by virtue of the effectivités cited by them. In this regard, the ICJ determined whether the parties' claims to sovereignty are based on activities evidencing an actual, continued exercise of authority over the islands, i.e., the intention and will to act as sovereign. ${ }^{93}$ It was decided by the ICJ that Malaysia

91 R. Haller-Trost, The Territorial Dispute between Indonesia and Malaysia over Pulau Sipadan and Pulau Ligitan in the Celebes Sea: A Study in International Law , Durham, IBRU Boundary and Territory Briefing, Volume 2 Number 2, 1995 , at page 5

92 Ibid

93 International Court of Justice, Sovereignty over Pulau Ligitan and Pulau Sipadan (Indonesia/Malaysia) Press Release 2002/39, 17 December 2002. http:// www.icj-cij.org/presscom/index.php?pr $=343 \& \mathrm{pt}=1 \& \mathrm{p} 1=6 \& \mathrm{p} 2=1$ Date Accessed:22 January 2014 
had exercised authority over the islands, and therefore was in ownership of the islands. ${ }^{94}$ The effect of the decision of the ICJ is that Indonesia was not happy based on the fact that neither party has actually has treaty-based title upon the islands. ${ }^{95}$ Thus, the decision made by the ICJ led to discontent on the part of Indonesia.

ii) The effects of the Case Concerning Sovereignty over Pedra Branca/ Pulau Batu Puteh, Middle Rocks and South Ledge (Malaysia/Singapore) 2008.

Since the dispute of Pulau Batu Putih or Pedra Branca has been settled by the ICJ in 2008, the ICJ awarded Pedra Branca (Pulau Batu Putih) to Singapore and Middle Rocks (Batuan Tengah) to Malaysia. South Ledge (Tubir Selatan) will be determined based on the territory South Ledge is located. Even though both Malaysia and Singapore agreed to abide and accept the decision meted out by the ICJ, the Malaysian Foreign Minister said that his country would search for the letters which would allow it the autonomy to build a Lighthouse on Pedra Branca. ${ }^{96}$ This shows that the Malaysian government is not happy with the decision made by the ICJ and Malaysia has the intention to ask the case to be reviewed if such letters were to be found. ${ }^{97}$ Thus, the decision made by the ICJ has led to discontent on the part of Malaysia.

Thus, the unpredictability or unexpected results of the aforesaid cases would not provide state parties with the comfort of certainty.

\section{Discontented States Unable to Take any Actions}

Discontented states are unable to take any actions on the decisions made by the ICJ probably because the discontented states' options

\footnotetext{
$94 \quad$ Ibid

95 Lessons to learn from Sipadan-Ligitan, The Jakarta Post, Jakarta, Friday, December 27 2002. http://www.thejakartapost.com/news/2002/12/27/lessonslearn-sipadanligitan.html Date Accessed 22 January 2014

96 Heather L. Jones. (2011). "Why Comply? An Analysis of Trends in Compliance with Judgments of the International Court of Justice since Nicaragua.", November 2011, http://works.bepress.com/heather jones/1 at page 67

$97 \quad$ Ibid
} 
are very limited.${ }^{98} \mathrm{At}$ the same time, the judgment meted out by the ICJ is considered final and binding upon the parties without the possible of appeal. This is stated in Article 60 of Statues of the ICJ. This Article 60 also gives the power of the ICJ to construe the meaning or scope of its judgment at the request of the state party.

However, an application for revision of a judgment could be made by state party based upon the discovery of certain facts which were unknown to the court. The request for revision must be made before the lapse of ten years from the date of judgment made by the ICJ. This is stated in Article 61 of Statues of the ICJ. On the other hand, the ICJ unlikely to revise its decision, absent of compelling new facts that would be decisive as to the maritime boundary issue. ${ }^{99}$

\section{Compliance with the Decision of the ICJ}

In regard to Article 94 of the UN Charter, state parties are required to comply with the decision of the ICJ. If the state parties refuse to abide to the judgment made by the ICJ, the other party may take the matter to the Security Council. The Security Council may make recommendations or decide what kind of measures to be taken to give effect to the judgment

\section{SOLUTION IN INTERNATIONAL ISLAMIC LAW (SIYAR)}

\section{Islamic International Law or Siyar}

Siyar in Arabic means the behaviour and conducts of Prophet Muhammad s.a.w during the time of war and peace which has been used and adapted by Imam Abu Hanifa ${ }^{100}$ for Islamic international

\footnotetext{
98 M. Imad Khan and David J. Rains, Doughnut Hole In The Caribbean Sea: The Maritime Boundary Between Nicaragua And Colombia According To The International Court Of Justice, Houston Journal Of International Law [Vol. $35: 3$ ] at page 604 .

99 Ibid.

100 Nu 'mān ibn Thābit ibn Zūtā ibn Marzubān better known as Imām Abū Hanīfah, (year $699-767 \mathrm{CE} / 80-148 \mathrm{AH}$ ) was the founder of the Hanafi school of Islamic jurisprudence.
} 
law. ${ }^{101}$ Imam Abu Hanifa also developed Islamic international law to be used for external relations with other states. ${ }^{102}$

During the time of classical Islamic jurists, Siyar was basically developed for law of war (Jihad), which includes the rules and conducts of war, cessation of war, distribution of booties, treatment of prisoners, law of revenue and etc. ${ }^{103}$ At the same time, Siyar also developed for the law of peace, such as treaty, diplomatic rights and privileges, and safe-conduct (Aman) toward non-Muslim visitors or traders for a temporary period of time. ${ }^{104}$ The period of friendly relationship between the Islamic Caliph Harun alRashid and Christian King Charlemagne, Siyar was further adapted for external relations with other states. ${ }^{105}$ Other international relations between Islamic and western Christian happened many times until the collapse of the Ottoman Empire in 1923 brought many interactions between Siyar and western international law. ${ }^{106}$

This theoretical approach is the application of Islamic principles i.e. International Islamic Law (Siyar). Since International Islamic Law (Siyar) is a very huge area, this article would only deal with the notion of Joint Administration. The International Islamic Law (Siyar) has been developed by the Muslims for more than 1,000 years

101 Dr Anowar Zahid and Dr Rohimi, Custom as a Source of Siyar and International Law: A Comparison of the Qualifying Criteria", (American) International Journal of Civil Society Law, (January 2010) vol. 8 issue 1, at page 36.

102 Ibid.

103 Ibid. at page 37; M. Khadduri, (1966), The Islamic Law of Nations: Shaybani's Siyar (trans.) (Baltimore, Maryland: The Johns Hopkins Press, at page 15.

104 Ibid.

105 Dr Anowar Zahid and Dr Rohimi, at page 36; H. Moinuddin, (1987), The Charter of the Islamic Conference and Legal Framework of Economic Cooperation among its Member States, Oxford: Clarendon Press, at page 38.

106 Dr Anowar Zahid and Dr Rohimi, at pages 38 and 39; H. Wheaton, (1845), History of the Modern Law of Nations, New York, at page. 555 quoted in M. Khadduri, (1955), War and Peace in the Law of Islam, Baltimore: The Johns Hopkins Press, at page 270 


\section{The Principle of Joint Administration}

The principle of joint administration refers to joint rights of administration between nations where two or more states exercise joint sovereignty over the same territory and its inhabitants. ${ }^{107}$ Oppenhiem describes joint administration or condominium as follows ${ }^{108}$ :-

"a piece of territory consisting of land or water is under joint tenancy of two or more States, these several States exercising sovereignty conjointly over it and over the individuals living thereon."

This notion of joint administration was first applied during the time of Abd al-Malik ibn Marwan, the fifth of Umayyad Caliph in 688 where Justinian II of the Byzantines agreed to set up a Joint Administration (Condominium) with Abd al-Malik ibn Marwan over Cyprus and later Armenia and Iberia (Georgia). ${ }^{109}$ The taxes collected in Cyprus, Armenia and Iberia (Georgia) had to be divided equally between the Muslims and the Byzantines ${ }^{110}$ and any revenue collected should be divided between them. ${ }^{111}$ The practice of the early Caliphs especially the application of joint administration by Caliph Abd al-Malik ibn Marwan could be accepted as part of Shariah through Urf'. Thus, the practises of the previous Caliphs could be accepted as part of Shariah but with modifications and need to be adaptable to suit contemporary situations. A parallel example could be drawn where Prophet Muhammad s.a.w accepted the practises of the previous prophets as part of Shariah with modifications or acceptance in total. ${ }^{112}$

107 S. Akweenda, (1997), International Law and Protection of Namibia's Territorial Integrity Boundaries and Territorial Claims, Kluwer Law International, at page 196

108 Lassa Oppenheim and Ronald Roxburgh, (2005), International Law: A Treatise, Volume 1-Peace, New Jersey: The Lawbook Exchange, Ltd., at page 308

109 A.N. Stratos, (1980), Byzantium in the Seventh Century, Volume V, Justinian II Leontius and Tiberius 685-711, Amsterdam: Adolf M. Hakkert-Publisher, at page 23

110 Ibid.

111 Ibid. at page 33

112 Dr Anowar Zahid and Dr Rohimi at page 54, quoted A. A. Thanwi, Behesti Jewr (Bengali trans. S. H. Faridpuri) (Dhaka: Emdadiya Library, 1990), at page 282. 
There are several ongoing joint administrations between Muslim majority countries, namely:-

a. An area ${ }^{113}$ jointly controlled by Sultanate of Oman and Ajman (a state within the United Arab Emirates) ${ }^{114}$; and

b. An area ${ }^{115}$ jointly controlled by Fujairah (a state within the United Arab Emirates) and Sharjah (a state within United Arab Emirates). ${ }^{116}$

Other joint administration arrangements are between Kuwait and Saudi Arabia in relation to Uqair Convention of 1922 and Agreement between the Kingdom of Saudi Arabia and the State of Kuwait concerning the submerged area adjacent to the divided zone 2 July $2000 .{ }^{117}$ The aforesaid mentioned joint administrations are examples where the practice of Caliph Abd al-Malik ibn Marwan has been practiced by the current Muslim sovereigns.

\section{Parallel Concept of Joint Administration and Joint Development}

There is a parallel similarity between Joint Administration and Joint Development where both could be used as alternative option to dispute settlement. The first joint development agreement was devised through an arrangement between Bahrain-Saudi Arabia whereby revenues arising from the exploitation of the oil resources of Fasht bu Saafa Hexagon area were being shared equally between the state parties and this arrangement is still ongoing. The significance of this first joint development agreement is the idea that this arrangement is derived from the principle of joint administration, which was enunciated by Caliph Abd al-Malik ibn Marwan over

113 An area called Masfut, located in a mountainous region 110 kilometers to the southeast of Ajman city. The territory stretching over $46 \mathrm{~km} 2$, is an international enclave bordering Oman.

114 Philippe Cadène and Brigitte Dumortier, Atlas of the Gulf States, Martinues Nijhoff Publishers, 2011, at page 68

115 Adjoining Ras al-Khaimah and Sharjah, with which it shares Dibba in the north and jointly administers a small enclave in the south, the Emirate of Fujairah consists of two mountainous territories washed by the Indian Ocean.

116 Philippe Cadène and Brigitte Dumortier, at page 71

117 The Uqair Convention of 1922 and Agreement between the Kingdom of Saudi Arabia and the State of Kuwait concerning the submerged area adjacent to the divided zone 2 July 2000 is a combination between Joint Administration and Joint Development. 
Cyprus, Armenia and Iberia (Georgia) ${ }^{118}$ for the purpose of dispute settlement with Justinian II of the Byzantines. All revenues and taxes in this arrangement were shared between these regional powers. Thus, a parallel concept can be drawn in relation to the principle of Joint Development whereby the disputed area is developed and any revenues arising from the exploitation of the natural resources are shared equally.

As for the relationship between Kuwait and Saudi Arabia, the "Neutral Zone" was established wherein both state parties have a common administrative responsibilities for the "Neutral Zone". After the discovery of oil on Al-Burqan field, the state parties jointly developed the "Neutral Zone" and the production form the Neutral Zone was shared between Kuwait and Saudi Arabia. Later, the state parties demarcated the "Neutral Zone" whereby the northern part of the "Neutral Zone" was administered directly by Kuwait and the southern part of the "Neutral Zone" was administered directly by Saudi Arabia. Despite the "Neutral Zone" being partitioned, the revenues of this arrangement are still being shared between the state parties.

Thus, based on the explanation on Kuwait and Saudi Arabia relationship, the initial common administrative i.e. Joint Administration is being morphed into Joint Development after the discovery of oil on Al-Burqan field. At the same time, the first Joint Development was devised and developed by Saudi Arabia in regard to the arrangement between Bahrain-Saudi Arabia.

\section{Joint Administration Agreement and Joint Development Agreement between Kuwait-Saudi Arabia.}

This part of the Article will examine the Kuwait and Saudi Arabia relationship where the common administrative i.e. Joint Administration of the "Neutral Zone" was later adapted to Joint Development upon the discovery of oil on Al-Burqan field. The "Neutral Zone"was laterpartitioned between Kuwait and Saudi Arabia and despite the area being partitioned, the revenues of this arrangement are being shared between the state parties. Three (3)

\footnotetext{
A.N. Stratos, at page 23
} 
treaties will be discussed in order to understand the nature of the Joint Administration Agreement and Joint Development Agreement between Kuwait-Saudi Arabia, namely:-

a) The Uqair Convention of 1922,

b) Agreement between Kuwait and Saudi Arabia Relating to the Partition of the Neutral Zone, 7 July 1965,

c) Agreement between the Kingdom of Saudi Arabia and the State of Kuwait concerning the submerged area adjacent to the divided zone 2 July 2000.

\section{The Uqair Convention of 1922}

The Uqair Treaty, which was signed on 2 December 1922, defined the boundaries between Saudi Arabia (then it was known as Kingdom of Najd) and Iraq and between Kuwait and Saudi Arabia. ${ }^{119}$ The Uqair Treaty of 1922 also dealt with a Saudi Arabia-Iraqi neutral zone and a Saudi Arabia-Kuwaiti neutral zone. This Article addresses the Joint Administration Agreement and Joint Development Agreement between Kuwait-Saudi Arabia neutral zone and not the Saudi Arabia-Iraq neutral zone.

The Neutral Zone was established by Uqair Convention of $1922^{120}$ between Saudi Arabia and Kuwait whereby both countries shared a common administrative responsibilities for the Neutral Zone - this convention mentions that "the Government of Najd and Kuwait will share equal rights until through the good offices of the Government of Great Britain a further agreement is made between Najd and Kuwait concerning it". The discovery of oil in the Al-Burqan field of Kuwait on the "Neutral Zone" in 1938 gave rise to much interest for both Kuwait and Saudi Arabia. ${ }^{121}$ Production from the Neutral Zone is shared between Kuwait and Saudi Arabia. ${ }^{122}$

\footnotetext{
119 E. Lauterpacht, C. J. Greenwood, Marc Weller and Daniel Bethlehem, The Kuwait Crisis: Basic Documents, (Cambridge International Documents Series, Volume 1, 1991), at page 80

120 The Boundary Convention Between Najd (Saudi Arabia) and Kuwait, (Treaty of Uqair), 2 December 1922

121 Richard F. Nyrop, Area Handbook for the Persian Gulf States, (U.S Govt. Printing Office, 1977), at page 93

122 Ibid
} 
Agreement between Kuwait and Saudi Arabia Relating to the Partition of the Neutral Zone, 7 July 1965

The Neutral Zone was divided in $1965^{123}$ through a treaty called "Agreement between Kuwait and Saudi Arabia Relating to the Partition of the Neutral Zone, 7 July $1965 " 124$ whereby the southern half of the mainland is administered directly by Saudi Arabia and the northern part by Kuwait ${ }^{125}$, and this agreement took effect in June $1970 .{ }^{126}$ However, each state continued to equally share the petroleum resources of the "Neutral Zone" after the Neutral Zone was divided ${ }^{127}$ which the Saudi government now calls the "Divided Zone". ${ }^{128}$

\section{Agreement between the Kingdom of Saudi Arabia and the State of Kuwait concerning the submerged area adjacent to the divided zone 2 July 2000}

The Partition Agreement of 1965 mentions that the boundary line between the two sections of the zone is to be the line which divides them into two equal parts. ${ }^{129}$ This agreement states that the sixmarine mile of the sea bed and subsoil adjoining the partitioned zone shall be annexed to the mainland of the partitioned zone. ${ }^{130}$ With regard to the submerged area beyond the territorial sea (six-marine mile), the Partition Agreement states that Kuwait and Saudi Arabia shall exercise their equal rights by means of joint exploitation. ${ }^{131}$

${ }^{123}$ Michael A. G. Bunter, The Promotion and Licensing of Petroleum Prospective Acreage, (Kluwer Law International, 2002), at pages 119-120.

124 Husain M. Albaharna, The Legal Status of the Arabian Gulf States: A Study of Their Treaty Relations and their International Problems, (Manchester University Press, 1968), at page 333.

125 Ali A. Hakim, The Middle Eastern States and the Law of the Sea, (Manchester University Press, 1979), at pages 107-108

126 Michael A. G. Bunter (fn 133) at pages 119-120.

127 Richard F. Nyrop (fn 131) at page 93

128 Anthony H. Cordesman, Saudi Arabia Enters the Twenty-First Century: The Political, Foreign Policy, Economic, and Enery Diemnsions, Centre for Strategic and International Studies, 2003, at pages 75 and 76.

129 Ali A. Hakim (fn 135) at pages 107-108

130 Ibid.

131 Ibid at 108; Jonathan I. Charney, David A. Colson, Lewis M. Alexander, Robert W. Smith, International Maritime Boundaries, Volume 5, (The American Society of International Law, Martinus Nijhoff Publishers, 2005), at page 3261 
Thus, this Partition Agreement has determined the six-marine mile (territorial sea) and the boundary line ends at the coast and has not been prolonged offshore. ${ }^{132}$

Kuwait and Saudi Arabia signed a treaty called "Agreement between the Kingdom of Saudi Arabia and the State of Kuwait concerning the submerged area adjacent to the divided zone 2 July 2000" for the purpose of dividing the submerged area adjacent to the Neutral Zone or Divided Zone. The application of the principle of equal distance was applied in this division whereby the partition of the neutral zone would not bring effect the limit of the islands, shoals and reefs ${ }^{133}$ except for a group of Faylakah Islands. ${ }^{134}$

The ownership of the natural resources in the submerged area is owned in common i.e. jointly owned by Kuwait and Saudi Arabia. ${ }^{135}$ In a nutshell, the Partition Agreement of 1965 and the Offshore Neutral Zone Agreement of 2000 determined that the natural resources of the Partitioned Zone or Neutral Zone and the Offshore Neutral Zone are subjected to joint ownership and joint development between Kuwait and Saudi Arabia.

\section{The Rationale for Adopting the Notion of Joint Administration}

The rationale for adopting the notion of joint administration is that the parties wanted to achieve mutually beneficial solution for the purpose of achieving peace and stability. The factors which state parties may consider in deciding to adopt joint administration are shared interest ${ }^{136}$, having close relations ${ }^{137}$ and in order to avoid military conflicts. ${ }^{138}$ Therefore, the ICJ should use this notion of joint administration in order to solve the disputes between the states parties. The state parties are not happy with the decisions

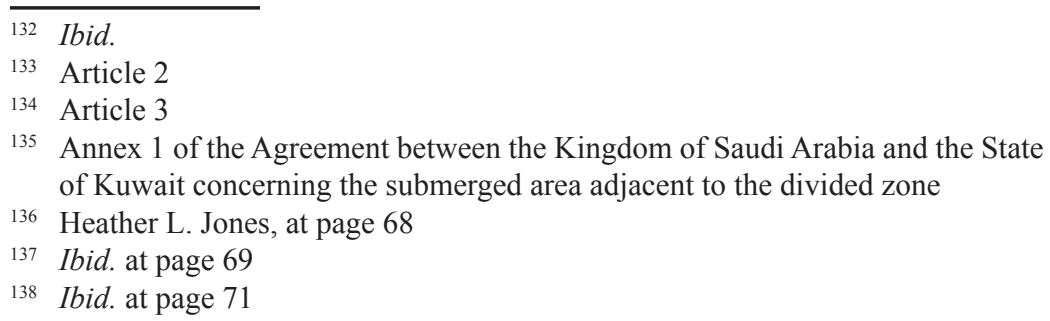


meted out by the ICJ, therefore, the adoption of the notion of joint administration which is originally from Islamic Law would provide an alternative solution of solving disputes between state parties.

The states parties which resorted to joint administration would normally have shared interest on the area of dispute. Since most of the disputes involve state parties which are neighbours, they need to get their act together to foster good relations. Thus, by having close relations between neighbouring countries, military conflicts might be averred. Explained below are some insights on why state parties resort to joint administration:-

a. Shared Interest

Normally the state parties who have possible disputes have shared interest on the area of dispute. In order to avoid having direct confrontation, parties would resort to the notion of joint administration. Therefore, joint administration would lead the parties to equally share the natural resource at the area of dispute.

b. Close Relations

The state parties based on economics, cultural, religion, history and family ties would normally resort to the notion of joint administration which would avoid both parties having conflicts.

c. Military Conflicts

The adoption of joint administration would in a way solve the dispute of the state parties and avoid the possibility of an armed conflict and the potential losses if the state parties decide to go to war.

\section{CONCLUSION}

The alternative solution provided by the International Islamic Law (Siyar) would bring peace and stability. This "mechanism of peace" provided by the International Islamic Law (Siyar) should be applied to all disputes throughout the world. 
The ICJ should be adapting to the principles which have been enunciated by the International Islamic Law (Siyar) as the alternative solution. The cases mentioned above have provided some indications that there would be more problems for the state parties in the future despite the non-appealable decisions made by the ICJ. Thus, the solutions provided by the ICJ do not provide everlasting peace and stability due to the fact that the decisions meted out by the ICJ are judge made law. On the other hand, the principles of International Islamic Law (Siyar) are based on Quran and Hadith which are not made by man.

\section{BIBLIOGRAPHY}

A. Thanwi. (1990). Behesti Jewr (Bengali trans. S. H. Faridpuri), Dhaka: Emdadiya Library.

Ali A. Hakim. (1997). The Middle Eastern States and the Law of the Sea, Manchester University Press.

Stratos, A.N. (1980). Byzantium in the Seventh Century, Vol V, Justinian II Leontius and Tiberius 685-711, Amsterdam: Adolf M. Hakkert Publisher.

Anthony Aust. (2010). Handbook of International Law, (2 ${ }^{\text {nd }}$ edi.), Cambridge: Cambridge University Press.

Anthony, H. C. (2003). Saudi Arabia Enters the Twenty-First Century: The Political, Foreign Policy, Economic, and Enery Diemnsions, Centre for Strategic and International Studies.

Antunes, N. S. M. 'The Pending Maritime Delimitation in the Cameroon v. Nigeria Case: A Piece in the Jigsaw Puzzle of the Gulf of Guinea', (2000), 15, International Journal of Marine and Coastal Law.

Bravender-Coyle, P. 'The Emerging Legal Principles and Equitable Criteria Governing the Delimitation of Maritime Criteria Governing the Delimitation of Maritime Boundaries Between States' (1988) 19 Ocean Development and International Law. Charney, A. 'The Delimitation of Ocean Boundaries', (1987), 18

Ocean Development and International Law 497.

Churchill, R. R., \& Lowe, A. V (1999). The Law of the Sea, (3 ${ }^{\text {rd }}$ edi), Manchester : Juris Publishing. 
Delimitation of the Maritime Areas between Canada and France (1992) 31 ILM.

Anowar Zahid, \& Rohimi, Custom as a Source of Siyar and International Law: A Comparison of the Qualifying Criteria”,(2010), (American) International Journal of Civil Society Law, January, vol. 8 issue 1.

E. Lauterpacht, C. J. Greenwood, Marc Weller \& Daniel Bethlehem. (1991), The Kuwait Crisis: Basic Documents, Cambridge International Documents Series, Volume 1.

Eileen Shim. Almost Every Country in the World Is Involved in a Territorial Dispute - Including the U.S, 2014, http://www. policymic.com/articles/86161/almost-every-country-in-theworld-is-involved-in-a-territorial-dispute-including-the-u-s Date Accessed 8 June 2014.

Energy-Pedia News. Cameroon to open coastal areas for oil exploration, 6 April $2010 \mathrm{http} / /$ www.energy-pedia.com/ news/cameroon/cameroon-to-open-coastal-areas-for-oilexploration Date Accessed 24 February 2013.

H. Moinuddin. (1987). The Charter of the Islamic Conference and Legal Framework of Economic Co-operation among its Member States, Oxford: Clarendon Press.

H. Wheaton. (1845). History of the Modern Law of Nations, New York.

Heather, L. J. Why Comply? An Analysis of Trends in Compliance with Judgments of the International Court of Justice since Nicaragua, November 2011, http://works.bepress.com/ heather_jones/1.

Heidi Currie. The Namibian-South African Boundary Question in terms of the Modern Law of Equitable Maritime Boundary Delimitation, FEIKE, Marine Regulatory Law and Environmental Management Advisers, 2005.

Husain M. Albaharna. (1968). The Legal Status of the Arabian Gulf States: A Study of Their Treaty Relations and their International Problems, Manchester University Press.

International Court of Justice. Reports of Judgments, Advisory Opinions and Orders, Case Concerning the Land and Maritime Boundary Between Cameroon and Nigeria (Cameroon v. Nigeria: Equatorial Guinea intervening), Judgment of 10 October 2002. 
International Court of Justice. Sovereignty over Pulau Ligitan and Pulau Sipadan (Indonesia/Malaysia) Press Release 2002/39, 17 December 2002. http://www.icj-cij.org/presscom/index. php?pr=343\&pt=1\&p1=6\&p2=1 Date Accessed:- 22 January 2014.

Jonathan, I. C. Progress In International Maritime Boundary Delimitation Law. (1994), American Journal of International Law. 88(2) April.

Jonathan I. Charney, David A. Colson, Lewis M. Alexander, Robert

W. Smith. International Maritime Boundaries, (2005), (Vol

5), The American Society of International Law, Martinus Nijhoff Publishers.

Kwiatkowska, B. 'Economic and Environmental Considerations in Maritime Boundary Delimitations' in Charney and Alexander (1993), (eds) International Maritime Boundaries, Vol I, The American Society of International Law: Martinus Nijhoff.

Land and Maritime Boundary between Cameroon and Nigeria. The Hague Justice Portal, http://www.haguejusticeportal.net/ index.php?id=6220 Date Accessed 23 February 2013.

Lassa Oppenheim \& Ronald Roxburgh. (2005). International Law: A Treatise, (Vol 1-Peace), New Jersey: The Lawbook Exchange, Ltd. Clark, New Jersey.

Lessons to learn from Sipadan-Ligitan. The Jakarta Post, Jakarta, Friday, December 27 2002. http://www.thejakartapost.com/ news/2002/12/27/lessons-learn-sipadanligitan.html Date Accessed 22 January 2014.

M. Imad Khan \& David J. Rains. Doughnut Hole In The Caribbean

Sea: The Maritime Boundary Between Nicaragua And Colombia According To The International Court Of Justice, Houston Journal Of International Law [Vol. 35:3].

M. Khadduri. (1966). The Islamic Law of Nations: Shaybani's Siyar (trans.) Baltimore: The Johns Hopkins Press.

M. Khadduri. (1955). War and Peace in the Law of Islam, Baltimore: The Johns Hopkins Press.

Michael A. G. Bunter. (2002). The Promotion and Licensing of Petroleum Prospective Acreage, Kluwer Law International Philippe Cadène and Brigitte Dumortier. (2011). Atlas of the Gulf States, Martinues Nijhoff Publishers. 
Steven Haines. A Note On The ICJ Judgment In Nicaragua V Colombia and its relevance to International Crime and Criminal Law, January 2, 2013, at page $2 \mathrm{http}$ ://acontrarioicl. com/2013/01/02/a-note-on-the-international-court-of-justicejudgement-in-nicaragua-v-colombia-and-its-relevance-tointernational-crime-and-criminal-law/ Date Accessed:- 21 February 2013.

Prosper Weil. (1989). The Law of Maritime Delimitation-Reflections Cambridge: Grotius Publications ltd.

R. Haller-Trost. The Territorial Dispute between Indonesia and Malaysia over Pulau Sipadan and Pulau Ligitan in the Celebes Sea: A Study in International Law, (1995) Durham, IBRU Boundary and Territory Briefing, Volume 2 Number 2.

Richard F. Nyrop. (1977). Area Handbook for the Persian Gulf States, U.S Govt. Printing Office.

S. Akweenda. (1977). International Law and Protection of Namibia's

Territorial Integrity Boundaries and Territorial Claims, Kluwer Law International.

Shi Jiuyong. Maritime Delimitation in the Jurisdiction of the International Court, Oxford Journals, Law \& Social Sciences, Chinese Journal of International Law, Volume 9, Issue 2, Pg. 271-291.

Sun Pyo Kim. (2004). Maritime Delimitation and Interim Arrangements in North East Asia, Dordrecht, Martinus Nijhoff Publishers.

Territorial Dispute and Maritime Delimitation (Nicaragua v. Colombia). International Court of Justice, Summary of the Judgment of 19 November 2012.

Territorial and Maritime Dispute (Nicaragua v. Colombia). The International Court of Justice (ICJ), Press Release, 19 November 2012, at page 9, http://www.icj-cij.org/docket/ files/124/17162.pdf Date Accessed:- 21 February 2013.

The Agreement between the Kingdom of Saudi Arabia and the State of Kuwait concerning the submerged area adjacent to the divided zone.

The Boundary Convention Between Najd (Saudi Arabia) and Kuwait, (Treaty of Uqair), 2 December 1922. 
The Economist. http://www.economist.com/blogs/americasview/2012/ 11/colombia-and-nicaragua Date Accessed:- 21 February 2013.

The Uqair Convention of 1922 and Agreement between the Kingdom of Saudi Arabia and the State of Kuwait concerning the submerged area adjacent to the divided zone 2 July 2000 is a combination between Joint Administration and Joint Development.

Vicuna, O. 'The Contribution of the Exclusive Economic Zone to the Law of Maritime Delimitation' (1989) 31 German Yearbook of International Law. 